\title{
Synergistic Evaluation of Data Presented by Archaeology, Anthropology, DNA Genealogy and other Disciplines Can Lead to Better Understanding of Past Events
}

\author{
Anton Perdih* \\ Faculty of Chemistry and Chemical Technology, University of Ljubljana, Europe
}

Submission: May 21, 2018; Published: June 18, 2018

*Corresponding author: Anton Perdih, Faculty of Chemistry and Chemical Technology, University of Ljubljana, Slovenia (retired), Europe, Emal: a.perdih@gmail.com

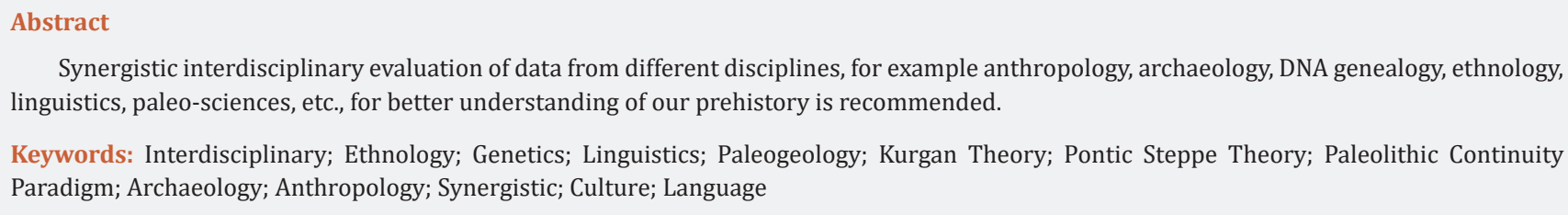

Synergistic interdisciplinary evaluation of data from different disciplines, for example anthropology, archaeology, DNA genealogy, ethnology, linguistics, paleo-sciences, etc., for better understanding of our prehistory is recommended.

Keywords: Interdisciplinary; Ethnology; Genetics; Linguistics; Paleogeology; Kurgan Theory; Pontic Steppe Theory; Paleolithic Continuity Paradigm; Archaeology; Anthropology; Synergistic; Culture; Language

\section{Short Communication}

In the last decade a new sub discipline of genetics had emerged, the DNA Genealogy [1,2]. The authors [3] confirmed the stochastic character of mutations in non-recombining parts of DNA in the Y chromosome, which is inherited along the male line, i.e. from father to sons only. This inheritance is not affected by changes in the living space, language, culture etc. The authors [3] demonstrated the first-order kinetics of mutations in the Y chromosome, presented the independently calibrated mutation rate constants, which are valid for different haplogroups and lineages. They presented the way of calculating time spans to the common ancestors.

They presented many new data about the time and direction of past events, published in several papers by Klyosov [4-9] as well as a large number of papers in Вестник Российской Академии ДНК-генеалогии [Proceedings of the Russian Academy of DNA Genealogy] and Вестник Академии ДНКгенеалогии [Proceedings of the Academy of DNA Genealogy], which are accessible at http://dna-academy.ru/proceedings/, and a lot of them at http://pereformat.ru/. There was published by Klyosov (et al.) also a number of books, mainly in Russian.

In this plentitude of publications several comparisons were made between the data provided by the DNA Genealogy and by other disciplines. Based on these comparisons, several improvements in understanding of data of other disciplines were suggested. One example is the admonition by Klyosov written in a lot of their contributions, i.e. $[4,5,7,9]$, addressing the times of living in particular localities as well as the times and directions of migrations of peoples having the Y Chromosome haplogroups R1a and R1b in Eastern Europe and Central Asia, as presented by the differences in their haplotypes and/or subclades.

According to them, see $[4,5]$, the haplogroup R1b people arrived from Central Asia to the Middle Volga River region about 13,000 years ago, forming there the pre-Kurgan and Kurgan cultures, expanding south towards the Caucasus Mountains and beyond them around 6,000 years ago. Those who remained north of the Caucasus Mountains formed later the Yamna Culture. Those who passed beyond the Caucasus Mountains expanded gradually across Egypt into the Central Africa resp. across the northern Africa onto the Iberian Penninsula and from there after about 4,800 years ago across the Western Europe. These people are the ancestors of most of present West-Europeans. The subclades of the Yamna Culture people are different from those of West-Europeans, although they derive from the same ancestors. The Yamna subclades are observed at present people outside the Yamna region mainly to the south and neither east nor west. This shows that the Yamna people did not expand west into Europe or east into the Central Asia but south till Mesopotamia. However, the Yamna people expanded south later than those who expanded to Western Europe. These data led also to the conclusion that the Kurgan Theory and the Pontic Steppe Theory of the Indo-European origin failed completely. 
According to Klyosov written in several of their contributions, i.a. [7,9], the haplogroup R1a people arrived Europe from Central Asia during the expansion of agriculture. In the late Neolithic they resided in Central Europe [10]. On the attacks of the R1b people around 4,500 years ago part of them took flight to the Russian plane and from there they expanded towards east and south, into the northern China, Iran, Near East, India. On this way they replaced in some previous settlements the R1b people and formed new ones. So the distribution of haplotypes and/ or subclades of present people and of ancient people helps to understand properly who expanded where and when.

The DNA Genealogy data presented by Klyosov were collected, illustrated and compared to data from other disciplines [11-14]. From these comparisons emerged i.a. a quite different view regarding the origin of Indo-Europeans and of the times when particular European linguistic groups started to be formed. The Proto-Slavic appeared to be the aboriginal European and Proto-Indo-European from the Paleolithic on, whereas the other European language groups formed later, as a result of immigrations of peoples of dissimilar origins. These comparisons led also to the conclusion that the Paleolithic Continuity Paradigm gave a too generalized explanation not supported by other data.

At the present stage of technique, it would be mandatory to determine the as complete as possible $\mathrm{Y}$ Chromosome sequences and to make available to the DNA Genealogy specialists all the SNP and STR data that could be traced in them. The differences in these subclades and/or haplotypes as well as the time spans to the common ancestors calculated from the SNP and STR data would be the anchor points for synergistic interdisciplinary evaluations of data were also archaeology, anthropology, ethnology, linguistics, paleogeology, etc. would be involved. Such a synergistic evaluation based on data and not on past interpretations would enable better understanding of our prehistory.

\section{References}

1. Klyosov AA (2009) DNA Genealogy, mutation rates, and some historical evidence written in the Y-Chromosome: I. Basic principles and the method J Genet Geneal 5: 186-216.
2. Klyosov AA (2009) DNA Genealogy, mutation rates, and some historical evidences written in Y-chromosome. II. Walking the map. J. Genet. Geneal. 5: 217-256.

3. Rozhanskii IL, Klyosov AA (2011) Mutation Rate Constants in DNA Genealogy (Y Chromosome). Advances in Anthropology 1(2): 26-34.

4. Klyosov AA (2011) Biological Chemistry as a Foundation of DNA Genealogy: the Emergence of Molecular History. Biochemistry (Mosc) 76(5): 517-533).

5. Klyosov AA (2012) Ancient History of the Arbins, Bearers of Haplogroup R1b, from Central Asia to Europe, 16,000 to 1500 Years before Present. Advances in Anthropology 2: 87-105.

6. Klyosov AA (2014) Reconsideration of the Out of Africa Concept as Not Having Enough Proof. Advances in Anthropology 4: 18-37.

7. Klyosov AA, Rozhanskii IL (2012) Haplogroup R1a as the Proto IndoEuropeans and the Legendary Aryans as Witnessed by the DNA of Their Current Descendants. Advances in Anthropology 2: 1-13.

8. Klyosov AA, Rozhanskii IL (2012) Re-Examining the Out of Africa Theory and the Origin of Europeoids (Caucasoids) in Light of DNA Genealogy. Advances in Anthropology 2: 80-86.

9. Rozhanskii IL, Klyosov AA (2012) Haplogroup R1a, its subclades and branches in Europe during the last 9000 years. Advances in Anthropology 2: 139-156.

10. Brandt G, Szécsényi-Nagy A, Roth Ch, Alt WK, Haak W (2015) Human paleogenetics of Europe - The known knowns and the known unknowns. J. Human Evolution 79: 73-92.

11. Perdih A (2016) Izvor Slovencev in drugih Evropejcev [Origin of Slovenes and other Europeans] ( $2^{\text {nd }}$ edn), Založništvo Jutro, Slovenia pp. 256.

12. Jandáček P, Perdih A (2017) Words for the Animal Elephant/Mammoth in Relation to the DNA Genealogy Data. Advances in Anthropology 7: 251-272.

13. Perdih A (2018) Continuity of European Languages from the Point of View of DNA Genealogy. International Journal of Social Science Studies 6(1): 18-32.

14. Jandáček P (2018) Mythological Beings Based on Mammoths. International Journal of Social Science Studies 6 (2): 1-9. 

(C) This work is licensed under Creative BY DOI: 10.19080/GJAA.2018.04.555646
Your next submission with Juniper Publishers will reach you the below assets

- Quality Editorial service

- Swift Peer Review

- Reprints availability

- E-prints Service

- Manuscript Podcast for convenient understanding

- Global attainment for your research

- Manuscript accessibility in different formats

( Pdf, E-pub, Full Text, Audio)

- Unceasing customer service

Track the below URL for one-step submission

https://juniperpublishers.com/online-submission.php 